Jurnal

Manajemen Kesehatan Indonesia

\begin{tabular}{llc}
\hline Volume 04 & No. 01 & April 2016 \\
\hline
\end{tabular}

\title{
Pengaruh Internal Marketing dan Kualitas Pelayanan BPJS Kesehatan Terhadap Kinerja Melalui Kepuasan Dokter di RSUD Ulin Banjarmasin)
}

\section{Effect of Internal Marketing and Service Quality BPJS Kesehatan Through Doctors Satisfaction Against Doctors Performance in Ulin Hospital Banjarmasin}

\author{
Rismayanti $^{1}$, Martha Irene Kartasurya, Nico L. Kana ${ }^{2}$ \\ 1) Mahasiswa Program Pascasarjana Magister Ilmu Kesehatan Masyarakat, Fakultas Kesehatan Masyarakat, \\ Universitas Diponegoro, Semarang \\ Email: riry1985@gmail.com \\ 2) FakultasKesehatanMasyarakat, UniversitasDiponegoro, Semarang
}

\begin{abstract}
Abstrak
Internal marketing dan kualitas pelayanan BPJS Kesehatan mempengaruhi kepuasan dokter yang selanjutnya menjadi faktor penentu kinerja dokter. Tujuan dari penelitian ini adalah mengalisis pengaruh internal marketing dan kualitas pelayanan BPJS Kesehatan terhadap kinerja dokter melalui kepuasan dokter di RSUD Ulin Banjarmasin.

Jenis penelitian ini adalah analitik dengan desain cross sectional. Pengumpulan data dilakukan secara angket dengan menggunakan kuisioner terstruktur. Subjek penelitian adalah semua dokter spesialis penyakit anak, penyakit dalam,ilmu bedah serta kandungan dan kebidanan yang bertugas di RSUD Ulin Banjarmasin yang memenuhi kriteria inklusi sebanyak 52 orang. Analisis data dilakukan dengan korelasi Pearson dan regresi linear berganda.

Hasil penelitian menunjukkan ada korelasi antara internal marketing dengan kepuasan dokter $(\mathrm{r}=0,584$, $\mathrm{p}=0,000)$, antara kualitas pelayanan BPJS Kesehatan dan kepuasan dokter $(\mathrm{r}=0,499, \mathrm{p}=0,001)$, antara kepuasan dokter dan kinerja dokter $(r=0,583, p=0,0001)$. Hasil penelitian dengan analisis regresi linear berganda menunjukkan bahwa internal marketing dan kualitas pelayanan BPJS Kesehatan memiliki kontribusi pengaruh terhadap kepuasan dokter sebesar 44,6\% sedangkan yang 55,4\% dijelaskan faktor lain. Kepuasan dokter memiliki kontribusi pengaruh terhadap kinerja dokter sebesar 32,7\% sedangkan yang 67,3\% dijelaskan variabel lain diluar model.

Disimpulkan bahwa internal marketing dan kualitas pelayanan berpengaruh terhadap kepuasan dokter yang selanjutnya berpengaruh terhadap kinerja dokter. Disarankan kepada BPJS Kesehatan untuk memperbaiki sistem pembiayaan INA-cbg's dan melakukan sosialisasi peraturan dan perundangan dengan lebih baik.

Kata kunci : internal marketing , kualitas pelayanan, kepuasan, Badan Pelaksana Jaminan Sosial Kesehatan
\end{abstract}

\begin{abstract}
Internal marketing and service quality BPJS are things that influence the level of satisfaction of doctors that becomes the deciding factor of doctor performance. The aim of this study is to find the influence of internal marketing and service quality performance of BPJS Kesehatan with doctor performance through doctor satisfaction at RSUD Ulin Banjarmasin.

This type of research is analytic with cross sectional design. The research method was developed using a questionnaire based on the literature. The number of respondents who came from the science
\end{abstract}


of internal medicine, pediatric, obstetrical and gynaecology, and surgery and met the inclusion criteria as many as 52 people were surveyed. Data was analyzed using Pearson correlation and multiple linear regression.

The results showed correlation between internal marketing to the satisfaction of doctors $(r=0.584$, $p=0.000$ ), between service quality BPJS and satisfaction of doctors $(r=0.499, p=0.001)$, between the satisfaction of doctors and the performance of doctors $(r=0.583, p=0.0001)$. Results of research by multiple linear regression analysis showed that the internal marketing and service quality BPJS have contributed influence on physician satisfaction of $44.6 \%$ while $55.4 \%$ described other factors. Physician satisfaction have contributed influence on physician performance by $32.7 \%$ while 67.3\% described other variables outside the model.

It was concluded that internal marketing and service quality effect on doctors satisfaction which in turn affect the performance of doctors. Suggested to BPJS Health to improve the financing system INA-CBG's and disseminate laws and regulations better.

Key words : internal marketing, service quality, satisfaction,

\section{PENDAHULUAN}

Pemasaran internal adalah suatu kegiatan menarik, mengembangkan, memotivasi dan mempertahankan karyawan-karyawan berkualitas melalui hasil pekerjaan yang memuaskan kebutuhan mereka. Pemasaran internal merupakan filosofi yang memperlakukan karyawan sebagai pelanggan serta merupakan strategi mengenai penentuan bentuk produk kerja guna memenuhi kebutuhan manusia. ${ }^{1}$ Yazidmenyatakan bahwa untuk memuaskan konsumen maka langkah pertama adalah memuaskan karyawannya terlebih dahulu. Kualitas pelayanan mencakup kualitas pelayanan internal yaitu pengambilan keputusan strategis dan kemampuan operasional melalui penggunaan pilihan strategis dan kualitas pelayanan eksternal. Karyawan yang puas terhadap pekerjaannya akan menjadi karyawan produktif, menurunkan biaya operasional dan menjamin kepuasan konsumen jika didukung oleh sistem manajemen dan teknologi yang tepat. ${ }^{2}$

Performa kerja yang buruk pada sektor pelayanan kesehatan akan mengakibatkan pelayanan kesehatan yang buruk, sulit diakses dan meningkatkan kelalaian medis. Rumah sakit adalah organisasi yang memberikan layanan dalam bidang kesehatan. Performa kerja tenaga medis yang rendah menurunkan kualitas pelayanan kesehatan karena praktek medis yang berbahaya. Masalah penurunan performa kerja dapat diakibatkan oleh ekspektasi pekerja yang tidak tercapai yang berarti pekerja tidak puas, keahlian yang kurang, sumber daya yang minim dan kekurangan motivasi. ${ }^{3}$

BPJS Kesehatan adalah lembaga yang baru berjalan sehingga memerlukan penyesuaian dan banyak mendapati masalah, hal utama yang sering menjadi pembahasan media massa adalah mengenai kualitas pelayanan yang diberikan oleh fasilitas kesehatan yang bekerjasama dengan BPJS. Kualitas pelayanan kesehatan di rumah sakit sangat dipengaruhi faktor-faktor, seperti kualitas sarana fisik, jenis tenaga kesehatan yang tersedia, obat dan alat kesehatan, proses pemberian layanan, dan pelayanan kesehatan oleh dokter. Faktor-faktor tersebut saling berinteraksi dan pada akhirnya mempengaruhi tingkat kepuasan pasien BPJS Kesehatan. ${ }^{4}$

RSUDUlin Banjarmasin memiliki tenaga dokter spesialis yang lengkap disemua divisi termasuk tenaga dokter sub spesialisnya. Total dokter spesialis di empat bagian besar (penyakit dalam, penyakit anak, kandungan dan kebidanan, dan penyakit bedah) adalah 56 dokter spesialis. Responden penelitian ini adalah dokter yang bertugas di ruang rawat inap non paviliun untuk pasien BPJS Kesehatan.

Jumlah pasien BPJS Kesehatan sekitar 70\% dari total pasien yang mendapat pelayanan kesehatan di RSUD Ulin Banjarmasin. Dapat dilihat bahwa mayoritas pasien di RSUD Ulin Banjarmasin adalah pasien peserta BPJS Kesehatan, hal ini dikarenakan RS Ulin Banjarmasin adalah rumah sakit pusat rujukan tertinggi dari dua provinsi Kalimantan selatan dan Kalimantan tengah. RS Ulin memiliki fasilitas penunjang medik terlengkap sehingga dapat melayani kasus kompleks yang membutuhkan perawatan lengkap. 
Terdapat kasus-kasus pemberian obat-obatan khususyang tidak ditanggung BPJS Kesehatan, klaim dalam jumlah besar yang tidak dibayarkan oleh BPJS Kesehatan dan kasus kartu kepesertaan BPJS Kesehatan yang tertunda. Terdapat kasus-kasus dengan diagnosa sekunder yang tidak terjamin BPJS. Hal ini berarti RS mengalami kerugian finansial. Jumlah pengaduan dari pasien selama tahun 2014 adalah 29 kasus, dimana yang terkait medis (dokter) sebanyak 17,3\% yang berkaitan dengan komunikasi dokter ke pasien yang dirasakan kurang baik, jam visite dokter yang tidak menentu, jam periksa poli yang seringkali terlambat dari jadwal dan waktu tunggu pasien yang panjang.

\section{METODE PENELITIAN}

Penelitian ini merupakan penelitian analitik observasional yang mengkaji keterkaitan sebab akibat antara internal marketing dan kualitas pelayanan BPJS Kesehatan terhadap kinerja melalui kepuasan dokter di RSUD Ulin Banjarmasin. Penelitian ini bersifat kuantitatif yaitu penelitian dengan menggunakan uji pengaruh antara variabel bebas dengan variabel terikat melalui variabel moderasi.Pendekatan waktu untuk pengumpulan data digunakan pendekatan cross sectional, merupakan desain penelitian yang membuktikan pengaruh variabel bebas dan variabel terikat dilakukan pengukuran variabel secara bersamasama.Adapun uji hipotesis / signifikansi yang digunakan yaitu uji signifikansi individual (t test) yaitu untuk menguji signifikansi variabel bebas yang terdapat dalam persamaan regresi secara individu berpengaruh terhadap nilai variabel terikat.

\section{HASIL}

Jenis kelamin responden mayoritas adalah lakilaki yaitu 43 orang atau $83 \%$ dari keseluruhan jumlah responden penelitian. Untuk lebih jelas dapat di lihat pada diagram di bawah ini:

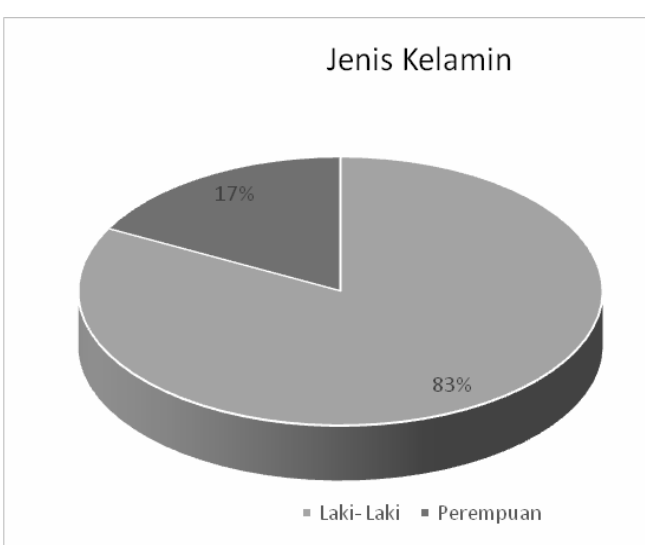

Gambar 1. Jenis Kelamin Responden

Responden berjumlah 52 orang. Nilai rata-rata umur responden adalah 50 tahun, nilai tengah adalah 51 tahun. Usia minimum responden adalah 37 tahun dan usia maksimum responden adalah 62 tahun.

Analisis korelasi Pearson figunakan untuk mencari arah dan kekuta hubungan antara variabel bebas dan variabel terikat dengan data berbentuk interval atau rasio.

Dari hasil tabel 1 diatas didapat hasil sebagai berikut:Variabel internal marketing. Nilai $\mathrm{r}=0,584$ dan bertanda positif, artinya variabel internal marketing berkorelasi searah dengan kepuasan dokter. Semakin baik internal marketing maka semakin baik pula tingkat kepuasan dokter. Nilai p $=0,0001(<0,05)$ berarti ada hubungan yang signifikan; variabel kualitas pelayanan.Nilai $\mathrm{r}=$ 0,499 dan bertanda positif, artinya variabel kualitas pelayanan berkorelasi searah dengan kepuasan dokter. Semakin baik kualitas pelayanan maka semakin baik pula tingkat kepuasan dokter. Nilai p $=0,0001(<0,05)$ berarti ada hubungan yang signifikan; Variabel kepuasan dokter.Nilai $\mathrm{r}=0,583$ dan bertanda positif, artinya variabel kepuasan dokter berkorelasi searah dengan kinerja dokter. Semakin baik kepuasan dokter maka semakin baik pula tingkat kinerja dokter. Nilai $=0,0001(<0,05)$ berarti ada hubungan yang signifikan.

Tabel 1. TabelKorelasi Pearson

\begin{tabular}{clcc}
\hline Variabel independen & Variabel dependen & $\mathrm{r}$ & $\mathrm{p}$ \\
\hline Internal Marketing & Kepuasan dokter & 0,584 & 0,0001 \\
Kualitas Pelayanan & Kepuasan dokter & 0,499 & 0,0001 \\
Kepuasan Dokter & Kinerja dokter & 0,583 & 0,0001 \\
\hline
\end{tabular}




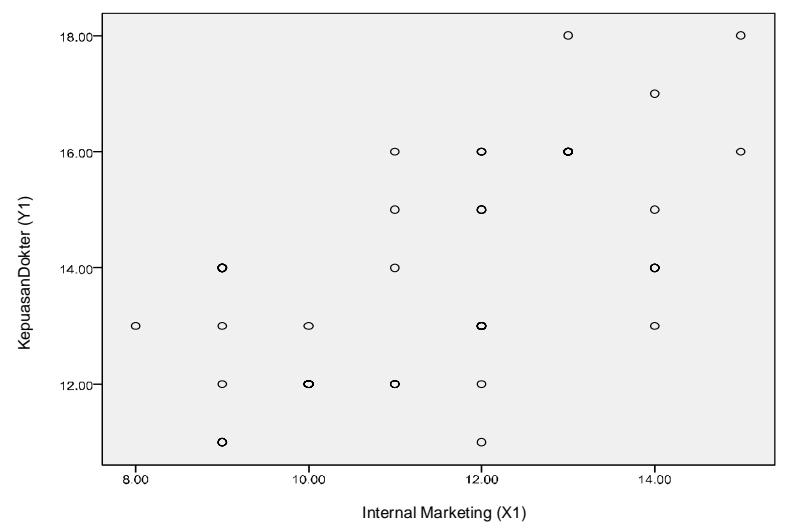

Gambar 2. Diagram tebar antara internal marketing dan kepuasan dokter

Gambar 2 diatas menunjukkan hubungan antara variabel internal marketingBPJS Kesehatan dengan kepuasan dokter, semakin meningkat nilai internal marketingBPJS Kesehatan maka nilai kepuasan dokter semakin meningkat.

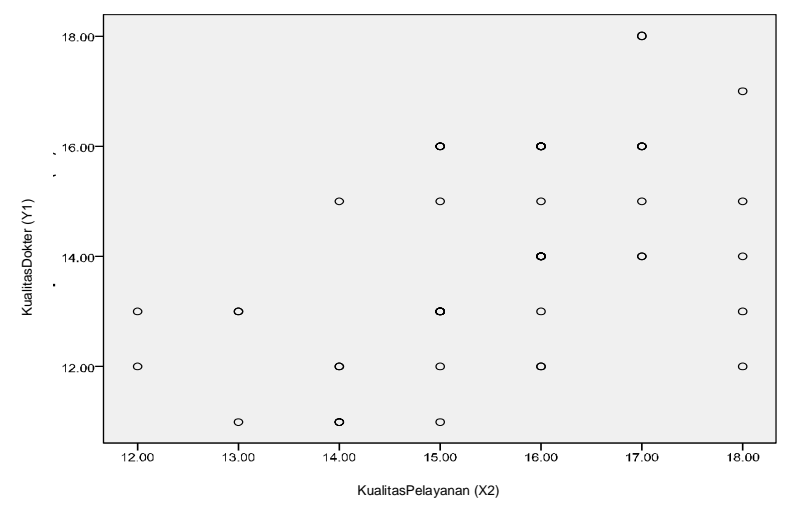

Gambar 3. Diagram tebar antara kualitas pelayanan BPJS dan kepuasan dokter

Gambar 3 diatas menunjukkan hubungan antara variabel kualitas pelayanan BPJS Kesehatan dengan kepuasan dokter, semakin meningkat nilai kualitas pelayanan BPJS Kesehatan maka nilai kepuasan dokter semakin meningkat.

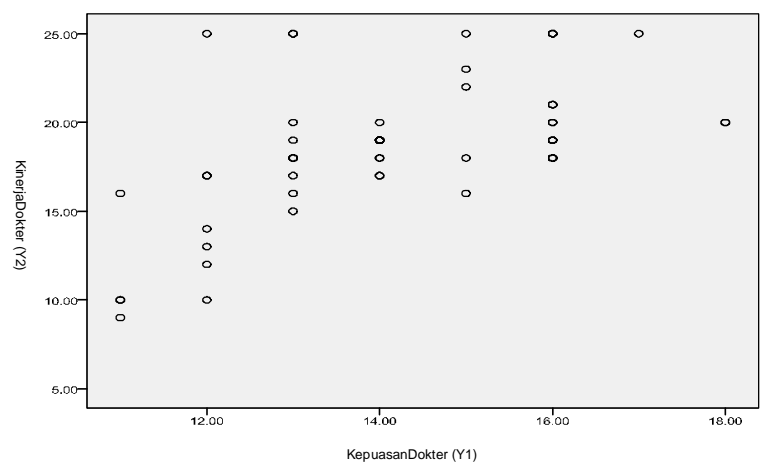

Gambar 4. Diagram tebar antara kepuasan dokter dan kinerja dokter

Gambar 4 diatas menunjukkan hubungan antara variabel kepuasan dokter dengan kinerja dokter, semakin meningkat nilai kepuasan dokter maka nilai kepuasan dokter semakin meningkat.

\section{Pengaruh Internal Marketing Dan Kualitas Pelayanan Terhadap Kepuasan Dokter}

Angka adjusted $R$ square sebesar 0,446, berarti bahwa variabel - variabel bebas yaitu internal marketing dan kualitas layanan memiliki kontribusi pengaruh terhadap kepuasan dokter sebesar 44,6\% sedangkan yang 55,4\% dijelaskan faktor lain di luar model.

\section{Pengujian Hipotesis (Tahap I)}

Pengujian hipotesis pengaruh internal marketing dan kualitas pelayanan terhadap kepuasan dokter dapat dijelaskan berdasarkan tabel 2.

Tabel 2 di atas menunjukkan bahwa nilai P value adalah 0,001 $(<0,05)$, berarti hipotesis pertama bahwa internal marketingberpengaruh positif terhadap kepuasan dokter di RSUD Ulin Banjarmasin terbukti. Nilai P value adalah 0,001 $(<0,05)$, berarti hipotesis kedua bahwa kualitas pelayanan berpengaruh positif terhadap kepuasan dokter di RSUDUlin Banjarmasin terbukti.Koefisien

Tabel 2. Tabel koefisien regresi (tahap I)

\begin{tabular}{lccc}
\hline Variabel & B & Std. Error & Sig. \\
\hline Kepuasan dokter (Y1) & 1,446 & 2,131 & 0,501 \\
Internal marketing (X1) & 0,478 & 0,106 & 0,000 \\
Kualitas pelayanan (X2) & 0,457 & 0,134 & 0,001 \\
\hline
\end{tabular}

adjusted $\mathrm{R}^{2}=0,446$ 
regresi $\hat{a}_{1}$ (beta) $=0,485$, karena bertanda positif $\left.{ }^{+}\right)$maka internal marketing $\left(\mathrm{X}_{1}\right)$ berpengaruh positif terhadap kepuasan dokter $\left(\mathrm{Y}_{1}\right)$ dan dapat diartikan bahwa semakin baik internal marketing maka semakin tinggi kepuasan dokter di RSUDUlin Banjarmasin. Koefisien regresi $\hat{a}_{2}$ (beta) $=0,370$, karena bertanda positif (+) maka kualitas layanan $\left(\mathrm{X}_{2}\right)$ berpengaruh positif terhadap kepuasan dokter $\left(\mathrm{Y}_{1}\right)$ dan dapat diartikan bahwa semakintinggi kualitas pelayanan maka semakin tinggi pula kepuasan dokter di RSUD Ulin Banjarmasin

\section{Pengaruh Kepuasan Dokter Terhadap Kinerja Dokter}

Angka adjusted $R$ square sebesar 0,327 , berarti bahwa variabel kepuasan dokter memiliki kontribusi pengaruh terhadap kinerja dokter sebesar $32,7 \%$ sedangkan yang 67,3\% dijelaskan variabel / faktor lain di luar model.

\section{Pengujian Hipotesis (Tahap II)}

Pengujian hipotesis ketiga pengaruh kepuasan dokter terhadap kinerja dokter dapat dijelaskan berdasarkan tabel 3.

Tabel 3 di atas menunjukkan bahwa nilai thitung dari pengaruh varibel kepuasan dokter terhadap kinerja dokter $=5,075>\mathrm{t}$ tabel $(50)$, $\mathrm{a}=0,05$, uji satu pihak, dengan angka signifikansi $=0,000<\mathrm{a}$ $(0,05)$. Hipotesis ketiga bahwa kepuasan dokter berpengaruh positif terhadap kinerja dokter di RSUDUlin Banjarmasin terbukti. Koefisien regresi $\hat{\mathrm{a}}_{3}$ (beta) $=0,583$ karena bertanda positif $(+)$ maka kepuasan dokter (Y1) berpengaruh positif terhadap kinerja dokter (Y2) dan dapat diartikan bahwa semakin tinggi kepuasan dokter maka semakin tinggi pula kinerja dokter di RSUD Ulin Banjarmasin.

\section{PEMBAHASAN}

Berdasarkan tabel di atas dapat diketahui bahwa $\mathrm{H}$ pertama; nilai t hitung dari pengaruh variabel internal marketing terhadap kepuasan dokter $=4,489>\mathrm{t}$ tabel $=1,684$ dengan angka signifikansi $=0,000<a(0,05)$. Dengan demikian hipotesis pertama bahwa internal marketingberpengaruh positif terhadap kepuasan dokter di RSUD Ulin Banjarmasin terbukti.

Penelitian yang dilakukan terhadap 52 responden di RSUD Ulin Banjarmasin dengan hasil internal marketingberpengaruh positif terhadap kepuasan dokter sejalan dengan pendapat dari beberapa peneliti seperti Arnett et al. ${ }^{1}$ Pemasaran internal yang berhasil akan menciptakan kepuasan kerja dan kebanggaan akan organisasi, akhirnya akan membentuk perilaku kerja karyawan yang positif. ${ }^{1}$ Perilaku kerja tersebut adalah komitmen untuk pelayanan pelanggan, kerjasama antar karyawan, dan komitmen organisasi. Hal ini menyebabkan kepuasan kerja menjadi hal yang penting karena akan mempengaruhi perilaku kerja karyawan. ${ }^{1}$ Khaled M melakukan penelitian di Malaysia menemukan internal marketing memiliki pengaruh kuat terhadap kepuasan kerja karyawan, dengan hasil regresi sebesar 40,9\%, dimensi orientasi internal marketing yang diteliti meliputi penelitian pasar internal, komunikasi internal dan respon internal. ${ }^{2}$ Kammerlind et al menunjukkan hasil yang bermakna antara kepuasan karyawan dengan kepuasan pasien pada sebuah penelitian di rumah sakit Swedia. Kondisi mental karyawan yang tidak puas terhadap pekerjaannya akan mengurangi komitmen dan keterikatan karyawan terhadap tempat kerja, akibatnya kepuasan pasien menurun. ${ }^{3}$ Teori ini sesuai dengan yang dikemukakan oleh Berry dan Parasuraman, karyawan yang terlibat dalam pelayanan jasa dapat memberikan performa yang lebih baik dalam interaksi dengan pelanggan, sehingga karyawan adalah pelanggan internal yang harus dipenuhi kepuasannya terlebih dahulu. ${ }^{4}$ Berdasarkan penelitian yang dilakukan para ahli tersebut diatas dapat disimpulkan bahwa hasil penelitian di RSUDUlin Banjarmasin sejalan dengan pendapat para ahli pemasaran dan menyebutkan bahwa terdapat pengaruh antara internal marketing dan kepuasan dokter.

Tabel 3. Tabel koefisien regresi (tahap II)

\begin{tabular}{lccc}
\hline \multicolumn{1}{c}{ Variabel } & B & Std. Erro & Sig. \\
\hline Kepuasan dokter (Y1) & 0,323 & 3,627 & 0,929 \\
Kinerja dokter (Y2) & 1,293 & 0,255 & 0,000 \\
\hline
\end{tabular}

adjusted $\mathrm{R}^{2}=0,327$ 
Hipotesis kedua merupakan hipotesis mengenai ada pengaruh antara kualitas layanan kepuasan dokter. Berdasarkan tabel di atas juga dapat diketahui bahwa nilai thitung dari pengaruh varibel kualitas layanan terhadap kepuasan dokter sebesar $3,420>t$ tabel $=1,684$ dengan angka signifikansi $=0,001<\mathrm{a}(0,05)$, dengan demikian hipotesis kedua bahwa kualitas layanan berpengaruh positif terhadap kepuasan dokter di RSUD Ulin Banjarmasin terbukti.

Hasil penelitian ini sejalan dengan penelitian Atkis et al , ketidakpuasan karyawan berakibat buruk pada pelayanan kesehatan yang diberikannya dan mengakibatkan loyalitas pasien terhadap rumah sakit menurun dan akhirnya menurunkan pendapatan rumah sakit. ${ }^{5}$ Metode perbaikan kualitas oleh manajemen rumah sakit menunjukan hasil yang bermakna antara kepuasan karyawan dengan kepuasan pasien pada sebuah penelitian di rumah sakit Swedia. ${ }^{6}$ Kondisi mental karyawan yang tidak puas terhadap pekerjaannya akan mengurangi komitmen dan keterikatan karyawan terhadap tempat kerja, akibatnya kepuasan pasien menurun. Kepuasan karyawan juga berkaitan erat dengan kualitas pelayanan kesehatan dan biaya kesehatan. Ketika dokter puas dengan pekerjaan dan rumah sakit, hal ini mengurangi tingkat tekanan mental, waktu tidak masuk kerja, jumlah pengunduran diri, ketidakmampuan dokter menyelesaikan masalah perkerjaan serta keluhan dari pasien., ${ }^{5,6}$ Herng-Ching Lin et al yang melakukan penelitian mengenai kepuasan kerja dokter terhadap sistem asuransi kesehatan nasional di Taiwan menemukan bahwa dokter memperoleh bayaran lebih rendah dibandingkan sistem pembayaran konvensional langsung dari pasien. ${ }^{7}$ Otoritas dan otonomi dokter terbatas oleh regulasi dari sistem. Hal-hal tersebut berdampak terhadap menurunnya kepuasan dokter terhadap sistem asuransi kesehatan nasional. ${ }^{7}$ Colby dan Stoddard et al berpendapat bahwa hilangnya otonomi dan otoritas dokter adalah hal yang menjadi prediktor kuat kepuasan dokter. ${ }^{8}$ Balciuniene et al mempelajari kepuasan kerja di rumah sakit Lithuania, hasilnya adalah dokter tidak puas dengan tingkat otonomi, kualitas hubungan dengan kolega, dan manajemen rumah sakit. Faktor rendahnya gaji dan beban kerja tinggi juga menjadi penyebab ketidakpuasan dokter. $^{9}$

Penelitian oleh peneliti mendapatkan hasil yang sesuai dengan penelitian diatas, otonomi dan otoritas dokter dirasa responden dibatasi oleh peraturan BPJS. Banyaknya perundangan dan regulasi BPJS Kesehatan, ketatnya alokasi dana klaim BPJS, besaran renumerasi yang diterima dokter dan alokasi dana untuk untuk sumber daya rumah sakit yang terpakai menjadi masalah utama dalam kepuasan dokter terhadap program BPJS Kesehatan. Komunikasi efektif juga menjadi faktor yang perlu diperhatikan oleh BPJS Kesehatan, mayoritas dokter masih merasa petugas kurang mensosialisasikan kebijakan dan aturan BPJS, tidak menanggapi permasalah yang dikemukakan dokter sesuai dengan harapan. Sumber daya manusia dalam BPJS Kesehatan sendiri kebanyakan masih memiliki pengetahuan dan keahlian yang kurang mencukupi, terlebih sistem ini adalah sistem yang baru berjalan sekitar satu tahun. Petugas BPJS di rumah sakit jumlahnya masih terbatas, dibandingkan beban kerja yang ditanggung dan tenggat waktu yang harus dicapai untuk menyelesaikan proses klaim, menjadi kendala pekerjaan sehingga dinilai lamban oleh dokter. Banyak fakta dilapangan yang membutuhkan solusi nyata, dan tidak dapat teratasi melalui aturan yang ada. Dokter yang merasa aspirasinya tidak didengar akan mendapat tempat untuk berpendapat. Responden mayoritas masih merasa aturan yang ada menjadi penghambat dalam bekerja bukan menjadi solusi, termasuk sistem rujukan berjenjang dan rujukan balik. Diskusi dua arah yang baik antara dokter sebagai pemberi layanan kesehatan dan BPJS Kesehatan sebagai pelaksana sistem akan menjadi solusi untuk menyelesaikan masalah, maka diskusi utilisasi review berkala yang dinilai responden masih kurang hendaknya diefektifkan dan menjadi agenda tetap bulanan.

H3 merupakan hipotesis mengenai pengaruh kepuasan dokter terhadap kinerja dokter. Berdasarkan tabel di atas dapat diketahui bahwa nilai thitung dari pengaruh varibel kepuasan dokter terhadap kinerja dokter $=5,075>\mathrm{t}$ tabel $(1,671)$ dengan angka signifikansi $=0,000<\mathrm{a}(0,05)$. Dengan demikian hipotesis ketiga bahwa kepuasan dokter berpengaruh positif terhadap kinerja dokter di RSUD Ulin Banjarmasin terbukti.

Hasil penelitian ini sejalan dengan pendapat beberapa peneliti seperti Hollyforde, kepuasan kerja adalah fenomena kompleks yang telah dipelajari dengan luas. Kepuasan kerja berkaitan dengan 
motivasi dan kinerja, motivasi memberikan dorongan pada karyawan tergantung tingkat kepuasan kerja mereka dan hasilnya tercermin dari sikap dan perilaku kerja. ${ }^{10}$ Berdasarkan hasil penelitian yang dilakukan peneliti terdahulu tersebut ternyata hasilnya sejalan dengan penelitian yang dilakukan di RSUD Ulin Banjarmasin bahwa terdapat pengaruh kepuasan dokter terhadap kinerja dokter. Kepuasan kerja dicapai apabila karyawan menyatu dengan organisasi, menunjukkan kemampuan terbaiknya dan komitmen, kepuasan kerja dan kinerja dipengaruhi oleh penghargaan oleh organisasi. Kreitner et al menyatakan berbagai faktor berpengaruh dalam kepuasan kerja, salah satunya adalah komitmen organisasi untuk melibatkan karyawan secara aktif dan mengatasi masalah tekanan mental di tempat kerja. ${ }^{11}$ Sebuah studi empiris oleh William et al menemukan hubungan antara kepuasan dokter dan kualitas pelayanan, variabelnya meliputi perilaku dokter dan kepuasan pasien. ${ }^{12}$ Penelitian di Florida menunjukkan peningkatan angka ketidakpuasan dokter terhadap profesinya berakibat pelayanan kesehatan yaitu rumah sakit dan pasien. Ketidakpuasan dokter dihubungkan dengan perilaku dokter yang buruk, kesalahan medis dan penurunan kualitas pelayanan terhadap pasien. ${ }^{13}$

Penelitian ini memiliki keterbatasan yaitu penilaian kinerja dokter dilakukan oleh dokter sendiri, bukan oleh atasan atau supervisor. Penilaian diri sendiri akan menghasilkan hasil yang cenderung menonjolkan kebaikan dan kelebihan diri sendiri. Kekurangan penelitian ini juga terbatas pada rumah sakit yang tipe A. Rumah sakit berbeda tingkatan maka biaya klaim INA-cbg's juga berbeda-beda. Rumah sakit tipe B,C dan D akan mendapatkan angka klaim yang lebih rendah dibandingkan dengan rumah sakit tipe A seperti RSUD Ulin Banjarmasin. Perbedaan ini mungkin akan menghasilkan tingkat kepuasan dan kinerja yang berbeda pula.

\section{KESIMPULAN}

Disimpulkan bahwa internal marketing dan kualitas pelayanan berpengaruh terhadap kepuasan dokter yang selanjutnya berpengaruh terhadap kinerja dokter. Disarankan kepada BPJS Kesehatan untuk memperbaiki sistem pembiayaan INA-cbg's dan melakukan sosialisasi peraturan dan perundangan dengan lebih baik.

\section{DAFTAR PUSTAKA}

1. D,Arnett.Using Job Satisfaction and Pride as Internal Marketing Tools" Camell hotel and restaurant administration quarterly. 2002; 88-96.

2. M, Khaled. The Relationship Between Internal Marketing Orientation and Employee Job Satisfaction in Public Sector.International Journal of Learning and Development. 2013; Vol 3; No 5.

3. Kammerlind, Peter. Climate for Improvement and The Effect on Performance in Swedish Healthcare - a Survey in The Country Council of Ostergotland.Total quality management and business excellence. 2004; Vol 15; No 7.

4. Berry LL, Parasuraman A. Marketing Services: Competing Through Quality. New York, The Free Press;1991.

5. Atkins, P Mardeen. Hapy Employees Lead to Loyal Patient. Journal of health care marketing.1996; Vol:16; No 4.

6. R, Krietner.Organizational Behaviour. Second Edition. Berkshire:McGraw-Hill; 2002.

7. Lin, Herng-Ching.Factors Related to Dissatisfaction with The National Health Insurance among Primary Care Physicians in Taiwan.Journal Chang Gung Med. 2003; Vol:26; No 2.

8. DC, Colby. Doctors and Discontent. Journal Health Aff. 2007; Vol:16; No: 6.

9. I, Balciuniene."Factors related to job satisfaction among Lithuanian dentist”. Baltic dental and maxillofacial jurnal. 2007. Vol:9.

10. W, Sunarso. Hubungan antara Kepuasan Kerja dan Peran Faktor-Faktornya terhadap Intensi Turnover pada Wiraniaga Toserba Progo Yogyakarta.Fakultas psikologi UGM; 2000.

11. R, Krietner. 2002. Organizational Behaviour. Second Edition. Berkshire:McGraw-Hill; 2002.

12. Williams E and Skinner AC. Outcomes of Physician Hob Satisfaction: ANarrative Review, Implications, and Directions for Future Research.Health care management review; 2003;119-140.

13. K, Marina. The importance of Job Satisfaction in Hospital Quality Process.Nordic School of Public Health; 2007. 